\title{
ABRIKOSSOFF TUMOR OF THE LARYNX
}

\author{
Murat Enoz', Erkan Kiyak ${ }^{2}$, Sami Katircioglu' ${ }^{2}$ Mine Gulluoglu ${ }^{3}$
}

Maresal Cakmak Military Hospital, Erzurum, Turkey: Deparment of ORL \& Head and Neck Surgery ${ }^{1}$; Istanbul University, School of Medicine, Turkey: Department of Otolaryngology, Head\&Neck Surgery²; Department of Pathology ${ }^{3}$

Summary: Case report about laryngeal localization of a granular cell tumor in a 38 years old female without recurrence over an observation period of two years.

Key words: Abrikossoff tumor; Granular cell tumor; Larynx

\section{Introduction}

Granular cell tumor (GCT, Abrikossoff tumor) is neoplasm of soft tissue that widely occurs a throughout the body. Originally, it was named granular cell myoblastoma by Abrikossoff in 1926 (1). GCT is a relatively uncommon and nearly always benign tumor (2). The head and neck area is the most common region of GCT onset, with a tendency to occur on the skin and tongue. Laryngeal locations account for 3 to $10 \%$ of occurrences in adult (5). A patient with laryngeal Abrikossoff tumor is presented.

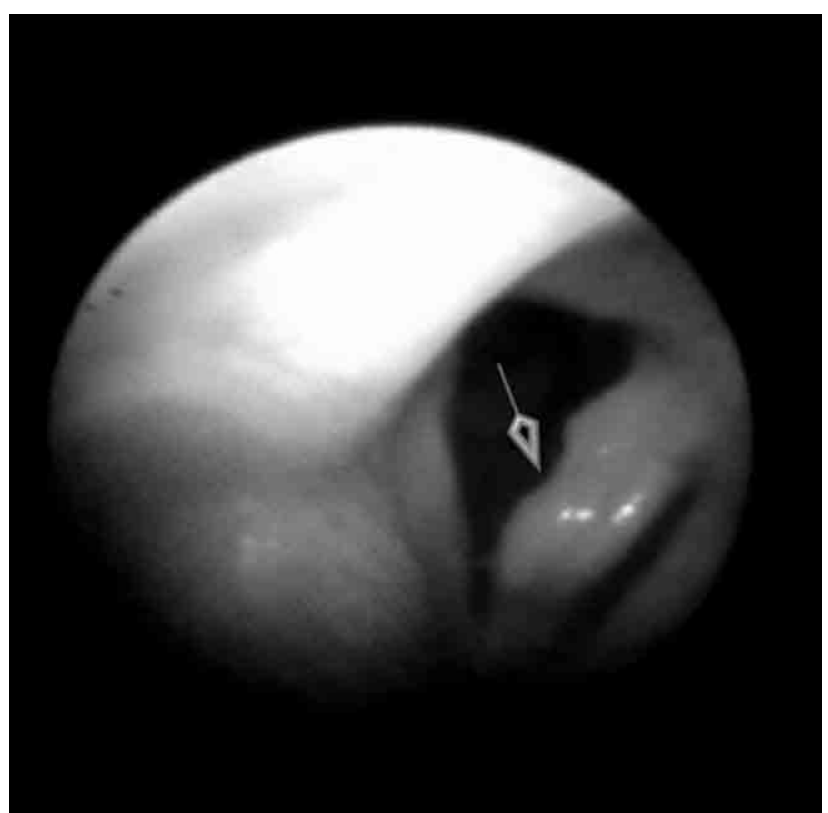

Fig. 1: The true left vocal cord region was affected by Abrikossoff tumor (arrow).
The histogenetic origin and etiology of this tumor are not well known. Different theories about tumor original have been offered. In fact, recent immunohistochemical and ultrastructural studies have supported the neurogenic origin of the tumor (4). Intracytoplasmic PAS positive granules were electronmicroscopically identified as lysosomes and /or autophagosomes (3). There is only one case in the literature in which the interarytenoid region has been affected by GCT (6).

\section{Case report}

A 38-year-old female patient was admitted to our clinic complaining of hoarseness and foreign body sensation. Her complaints started 6 months before admission and she stated that they had increased over time. A laryngeal endoscopic examination revealed a mass with a smooth surface involving the left true cord (Fig. 1). There was no cervical lymphadenopathy, and the rest of the head and neck examination was normal. The patient was neither a smoker not a drinker, and had no pertinent medical history. Informed consent was obtained before enrollment of the patient. Microlaryngoscopic surgery was performed under general anesthesia, and a histopathologic examination revealed a granular cell tumor. The tumor was excised completely. The postoperative course was uncomplicated. The histopathologic examination revealed GCT with free margins and pseudoepitheliomatous changes on the surface (Fig. 2). Two years of patient follow up were uneventful and no recurrence was found.

\section{Discussion}

Granular cell tumors are benign and rare lesions. They can arise in any organ in the body, but they have been mostly seen on the upper aerodigestive tract. The anterior part of the 


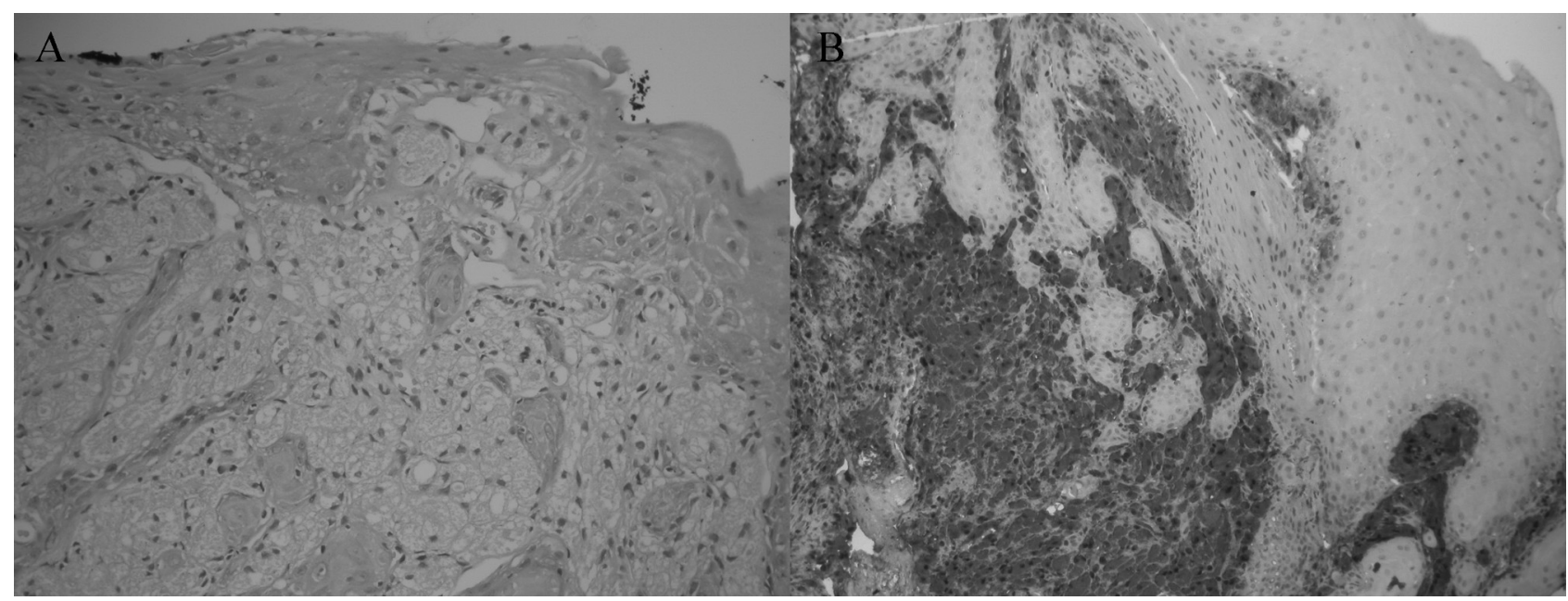

Fig. 2: The tumor composed of large cells having small-round-oval nuclei and large granular cytoplasm (A) which shows S100 protein immunoreactivity (B). There is pseudoepitheliomatous hyperplasia of the overlying epithelium (H\&E and S100, original magnification $100 \mathrm{X})$.

tongue and the larynx are the first and second most common sites of these tumors, respectively (2). Symptoms depend on the localization and size of the tumor. The most common symptoms for laryngeal granular cell tumors are hoarseness, cough, hemoptysis, stridor, otalgia, and dysphagia (5).

Fifty to $65 \%$ of laryngeal granular cell tumors have pseudoepitheliomatous hyperplasia, which can lead to misinterpretation owing to the similarity of these lesions to squamous cell carcinoma $(2,6)$. Carcinoma imitating pseudoepitheliomatous changes may lead the surgeon to inappropriate and irreversible treatments.

The treatment procedures of GCT depend on the site and extension of the lesion. A local excision by microscopic laryngoscopy or endoscopy is performed for small tumors, whereas laryngofissure, partial laryngectomies, and irradiation are used for the largest tumors (5).
We have been following up our patient for two years and no recurrence has as of yet been found.

\section{References}

1. Abrikossoff A. Über Myome, ausgehend von der quergestreiften willkürlichen Muskulatur. Virchows Archiv pathol Anat Physiol 1926;260:215-33.

2. Fanburg-Smith JC, Meis-Kindblom JM, Fante R, Kindblom LG. Malignant granular cell tumor of soft tissue: diagnostic criteria and clinicopathologic correlation. Am J Surg Pathol. 1998 Jul;22(7):779-94.

3. Ghadially F. N. Diagnostic Electron Microscopy of Tumors, Butterwoths London 1980;109-15.

4. Lassaletta L, Alonso S, Ballestin C, Martinez-Tello FJ, Alvarez-Vicent JJ. Immunoreactivity in granular cell tumours of the larynx. Auris Nasus Larynx. 1999 Jul;26(3):305-10.

5. Pelucchi S, Amoroso C, Grandi E, Carinci F, Pastore A. Granular cell tumour of tbe larynx: literature review and case report. J Otolaryngol 2002;31:234-5.

6. Toprak M, Oz F, Oktem F, Acioglu E, Yilmaz S. Granular cell tumour of the larynx. J Otolaryngol. 2005 Oct;34(5):363-5.

Submitted January 2007. Accepted March 2007.

\section{Corresponding author:}

Murat Enoz, M.D., Maresal Cakmak Military Hospital, 25700, Yenisehir, Erzurum/Turkey, e-mail: muratenoz@gmail.com 